\title{
A Tribute to Patrick W. Colgan 1944-2004
}

\section{IAN THOMPSON}

Canadian Forest Service, 1219 Queen Street East, Sault Ste. Marie, Ontario P6A 5M7 Canada; e-mail: Ian.Thompson@ NRCan-RNCan.gc.ca

Thompson, Ian. 2010. A tribute to Patrick W. Colgan 1944-2004. Canadian Field-Naturalist 124(4): 357-366.

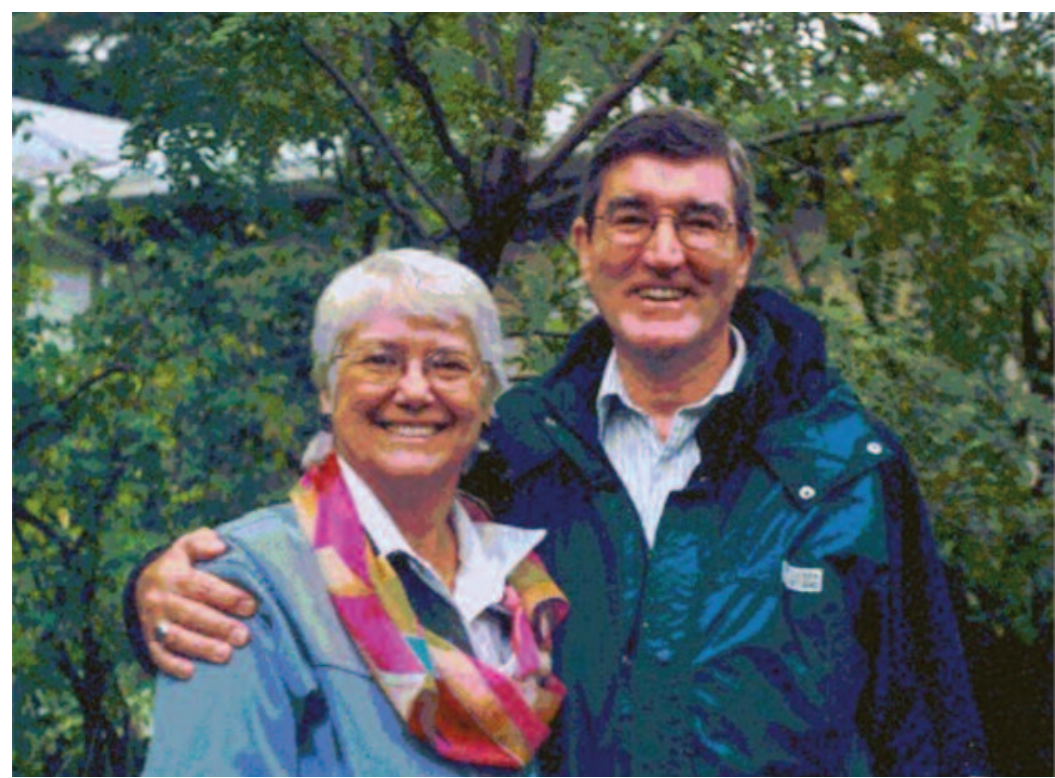

Patrick Colgan and partner Marcia Sweet, at home in Burlington in 2001.

Patrick Colgan died on 21 July 2004 from the amyotrophic lateral sclerosis (ALS or Lou Gehrig's disease) that had been diagnosed at the end of April 2003. Patrick was married to Valerie Salmond from 1966 to 1986. They had two sons, Andrew and Jeffery. After a career teaching at Queen's University in Kingston, Patrick accepted an administrative position with the Canadian Museum of Nature and he and his partner, Martha Sweet, moved to Ottawa. At the time of his death, Patrick was the director of research programs for Royal Botanical Gardens (RBG), in Hamilton and Burlington, Ontario. RBG had accorded him emeritus status during the latter period of his illness, in 2004. He is sadly missed by Marcia and family.

Patrick earned an Honours BA (with a major in animal psychology) in 1967 from the University of Toronto and a Master's degree in psychology from Harvard University. After receiving his $\mathrm{PhD}$ from Cornell University in 1971, he accepted a position as assistant professor in the Biology Department at Queen's University. From 1979-80, he was the "Royal Society Suffield Scholar", at Sussex University, England. In 1984, he was promoted to Professor of Biology at Queen's University and served as Associate Head and Acting Head of the Department for several periods from 1987 through 1991. He also served as the Chair of Life Sciences, School of Graduate Studies from 1985-87. Patrick supervised 19 master's degree students, 7 doctoral dissertations, and 5 post-doctoral fellows, and served on the supervisory committees of more than 30 other graduate students.

Patrick was an expert in fish behaviour, focussing on aspects of motivation and proximate causation, and with his students, published many quantitative papers on the subject. Between 1975 and 1986, he wrote or co-edited four books on the quantitative study of animal behaviour. Patrick and his graduate students produced a remarkable number of publications, many of which continue to be cited (see following bibliography). He served as the editor of Animal Behaviour in 19821985, was President of the Animal Behaviour Society from 1989-90 and was elected a Fellow in 1991. Patrick was a voracious reader and he was in constant demand as a reviewer of books for journals and news- 
papers because of the quality of his reviews. He was the book review editor for Behavioural Processes from 1993-1997 and for Global Biodiversity 1994-1997. As well, he was a frequent contributor of reviews to The Canadian Field-Naturalist in from 1981 to 2002 and the Canadian Book Review Annual from 1993 to 2004. He continued to do book reviews up until the week of his death.

Patrick left Queens to join the Canadian Museum of Nature 4 June 1991 after being individually recruited as Assistant Director Collections and Research. In a reorganization in 1994 he became Vice President for Science and Education. I think that perhaps Patrick felt that joining the museum was an opportunity to affect changes to national science policies, and certainly he had become interested in science management during the latter years of his tenure at Queen's. During this short period on the federal scene, he also served as a lecturer at the Canadian Centre for Management Development. While at the Canadian Museum of Nature, he instituted and led a Task Force on Canadian Biosystemics, authoring a major report on the state of systematics research and capacity in Canada in 1992. Unfortunately, not all the years at the Museum were the happiest for Patrick. He had to preside over downsizing of his staff in 1993 and then, ultimately, he too was caught in the net of continuing upheaval within the museum when his own position was terminated in April, effective 12 July 1997. Subsequently he wrote a moving essay on the affects of downsizing published in the Globe and Mail 19 September 1997 page A18. Facts and Arguments: After downsizing: letting go, moving on. When I lost my job, Canada lost another established scientist. But Marcia got a less challenging garden, a university got my science library, and the world has a new pair of B\&B owners" which described his search for a new role and resettlement in warmer climate of the Niagara-on-the Lake in southern Ontario as tourist accommodation entrepreneurs

Immediately following his departure from the museum, Patrick made an extraordinarily generous gift of 10000 books from his immense personal library, many volumes of which were rare, to Algoma University College in Sault Ste. Marie, and of another 1000 books to University of Northern British Columbia. At the same time, he donated his massive collection of more than 300000 reprints to Memorial University.

After three years of B\&B and sessional lecturer in evolution at Brock University, in 2001 he became Director of Research and Natural Lands at Royal Botanical Gardens. Here, he supervised the herbarium, library, research and natural lands projects, researchers and ecological managers. Patrick was also responsible for the stewardship of approximately 1000 hectares of natural lands that are owned and managed by RBG and he represented the institution in collaborations, such as the Bay Area Restoration Council. In 2001,
Patrick explored a new relationship between RBG and indigenous peoples that resulted in a First Nations internship program in ethnobotany at RBG, supported by the Museum Assistance Program of the Government of Canada.

Patrick had a wonderful sense of humour, and enjoyed witticisms to no end. He sent the following memo to Queen's Financial Services Department that was printed in Biology this Week (the Queen's Biology Department newsletter): "For some time I have received some of my cheques from you made out to Patricia Colgan. Please be assured that this is an error, proof of which I should be happy to furnish if requested."

He was an avid chorister and spent many happy years singing with the Kingston Symphony Choral Society. Indeed, his curriculum vitae, submitted for promotion to Professor at Queen's University, contained two pages listing the choral works with which he had been involved during his time in Kingston. He continued his singing in Ottawa and again in Niagara/ Hamilton, until his illness forced him to give up this joy in his life. Another Patrick passion was rare books, and many a graduate student was dragged in-tow into rare book stores across North America, while attending various conferences.

I can only imagine the frustration that such an illness brought to a man who was so extraordinarily full of energy. Patrick loved life. His enthusiasm for debate, knowledge, ideas, detailed thinking, books, mathematics, singing, sports, and family were contagious for those of us who were blessed enough to know him well. When I met Patrick, he was the consummate academic, brimming with ideas and revelling in constant questioning.

My personal involvement with Patrick began in 1981, when I asked Queen's University Biology Department to consider taking a mature student (some would have argued differently!) on an educational leave from the federal government to do a doctorate. There was apparently disagreement at the school over the issue, as this kind of arrangement had not previously been done. But, Patrick, ever respectful of motivated people and new ideas, simply asked "why not?", and stated emphatically that he would gladly step up as supervisor. And so, an unlikely alliance began between a forest wildlife ecologist and a fish behaviourist, and I found myself in a lab surrounded by fish folks. Patrick was a wonderful supervisor and participated fully with his students, academically in the lab, athletically at the rink and on the squash courts, and socially at the "Grad Club" or at various dinners at his home. A beer at the Grad Club after playing a hockey game was not an afternoon wasted to him. Aside from the alacrity and probity of the man, what probably struck me most about Patrick was that he never used what he knew was a superior intellect to demean others. Patrick became one of two people who were 
highly influential in my professional life, as I know he also was for many other students who were fortunate enough to pass through his lab. He was, without a doubt, the most erudite person that I have ever met and all of us students benefitted immensely from his guidance, passion, and knowledge. The legacy of Patrick Colgan is a large number of well-established, wellrecognized researchers doing important work across this country and abroad. I shall always remember his daily slogan: "onwards and upwards!" and I shall miss it.

\section{Acknowledgments}

My appreciation for their contributions to Marcia Sweet, Patrick's partner, to David Galbraith, Head of Scientific Development, Royal Botanical Gardens, to Raleigh Robertson, Head, Department of Biology, Queen's University, and to the late Florence (Susan) Smallman of Kingston.

\section{Books Authored or Edited:}

Colgan, Patrick. Editor. 1978. Quantitative Ethology. John Wiley \& Sons, New York. ISBN: 0471022365

Colgan, Patrick W. 1983. Comparative Social Recognition. John Wiley \& Sons, New York. ISBN: 0471093505

Colgan , Patrick W., and Renâe Zayan. Editors. 1986. Quantitative Models in Ethology. Université Paul Sabatier, Privat, Toulouse, France. ISBN: 2708987089.

Colgan, Patrick. 1989, Animal Motivation. Kluwer Academic Publishers Group, London. ISBN: 0412318504

\section{Scientific papers (in chronological order)}

Colgan, P. W. 1973. Motivational analysis of fish feeding. Behaviour 45: 38-66.

Colgan, P. W., and D. Ealey. 1973. The role of woody debris in nest site selection by pumpkinseed sunfish, Lepomis gibbosus. Canadian Fisheries Research Board Journal 30: 853-856.

Colgan, P. W., F. Cooke, and J. T. Smith. 1974. An analysis of group composition on assortatively mating populations. Biometrics 30: 693-696.

Colgan, P. W. 1974. Burying experiments with banded killifish, Fundulus diaphanous. Copeia 1974: 258-259.

Colgan, P. W. 1975. Self-selection of photoperiod as a technique for studying endogenous rhythms in fish. Journal of Interdisciplinary Cycle Research 6: 203-211.

Colgan, P. W., P. K. Ballantyne, and N. V. H. Wilson. 1976. Numerical taxonomy of hybridizing Lepomis centrarchidae in Lake Opinicon, Ontario, Canada. Canadian Journal of Zoology 54: 42-47.

Colgan, P. W., and M. R. Gross. 1977. Dynamics of aggression in male pumpkinseed sunfish (Lepomis gibbosus) over reproductive phase. Zeitschrift Fur Tierpsychologie 43: 139-151.

Colgan, P. W. 1978. Modeling. In Quantitative Ethology. Edited by P. W. Colgan. Wiley Inter-Science, New York.

Colgan, P. W., and T. J. Smith. 1978. Multidimensional contingency table analysis. Pages 146-174 in Quantitative Ethology. Edited by P. W. Colgan. Wiley, New York.

Ballantyne, P. K., and P. W. Colgan. 1978. Sound production during agonistic and reproductive behaviour in the pumpkinseed (Lepomis gibbosus), the bluegill (L. macrohirus) and their hybrid sunfish. I. Context. Biology of Behaviour 3: 113-135.

Ballantyne, P. K., and P. W. Colgan. 1978. Sound production during agonistic and reproductive behaviour in the pumpkinseed (Lepomis gibbosus), the bluegill (L. macrohirus) and their hybrid sunfish. 2. Recipients. Biology of Behaviour 3: 207-220.

Ballantyne, P. K., and P. W. Colgan. 1978. Sound production during agonistic and reproductive behaviour in the pumpkinseed (Lepomis gibbosus), the bluegill (L. macrohirus) and their hybrid sunfish. 3. Response. Biology of Behaviour 3: 221-232.

Colgan, P. W., W. A. Nowell, M. R. Gross, and J. W. A. Grant. 1979. Aggressive habituation and rim circling in the social organization of bluegill sunfish (Lepomis macrochirus). Environmental Biology of Fishes 4: 29-36.

Colgan, P. W. 1979. Is super territory strategy stable? American Naturalist 114: 604-605.

Colgan, P. W., and N. Costeloe. 1980. Plasticity of burying behavior by the banded killifish, Fundulus diaphanous. Copeia 1980: 349-351.

Colgan, P. W., and P. J. B. Slater. 1980. Clustering acts from transition matrices. Animal Behaviour 28: 965-966.

Colgan, P. W., and P. Taylor. 1980. Sex-ratio in autoparasitic hymenoptera. American Naturalist 117: 564-566. Healey, R. F., F. Cooke, and P. Colgan. 1980. Demographic consequences of snow goose brood rearing conditions. Journal of Wildlife Management 44: 900-905.

Slater, P. J. B., S. A. Ince, and P.W. Colgan. 1980. Chaffinch Fringilla coelebs song types: their frequencies in the population and distribution between repertories of different individuals. Behaviour 75: 207-218.

Colgan, P. W., W. A. Nowell, and N. W. Stokes. 1981. Spatial aspects of nest defence by pumpkinseed sunfish (Lepomis gibbosus): stimulus features and an application of catastrophe theory. Animal Behaviour 29: 433-442.

Brown, J. A., and P. W. Colgan. 1981. The use of lateralbody bar markings in identification of young-of-year sunfish (Lepomis) in Lake Opinicon, Ontario. Canadian Journal of Zoology 59: 1852-1855.

Yee, J., L. Broekhoven, P. Colgan, and R. Harmsen. 1981. Maximal growth rate determination using continuous culture. Journal of Protozoology 28: 146-148.

Brown, J. A., and P .W. Colgan. 1982. The inshore vertical distribution of young-of-year Lepomis in Lake Opinicon, Ontario. Copeia 1982: 958-960.

Colgan, P. W., and J. A. Cross. 1982. Laboratory food patch exploitation in the algae-eater (Gyrinocheilus ayomonieri). Biological Behaviour 7: 109-117.

Colgan, P. W., J. A. Cross, and P. H. Johansen. 1982. Guppy behavior during exposure to a sub-lethal concentration of phenol. Bulletin of Environmental Contamination and Toxicology 28: 20-27.

Grant, J. W., and P. W. Colgan. 1983. Reproductive success and mate choice in the Johnny darter, Etheostoma nigrum (Pisces: Percidae). Canadian Journal of Zoology 61: 437446.

Grant, J. W. A., and P. W. Colgan. 1984. Territorial defence of the male Johnny darter, Etheostoma nigrum, Environmental Biology of Fishes 10: 261-269.

Clarke, S. E., P. W. Colgan, and N. P. Lester. 1984. Courtship sequences and ethological isolation in two species of sunfish (Lepomis spp.) and their hybrids. Behaviour 91: 93-114. 
Brown, J. A., and P. W. Colgan. 1984. The ontogeny of feeding behaviour in four species of centrarchid fish. Behavioral Proceedings 9: 395-411.

Colgan, P., and B. Silburt. 1984. Feeding behavior of the central mud minnow, Umbra limi, in the field and laboratory. Environmental Biology of Fishes 10: 209-214.

Colgan, P. W., and T. J. Smith. 1985. Experimental analysis of food preference transitivity in pumpkinseed fish (Lepomis gibbosis). Biometrics 41: 227-236.

Hilder, B. E., and P. W. Colgan. 1985. Territorial behaviour of male Nannothemis bella (Uhler) (Anisoptera: Libellulidae). Canadian Journal of Zoology 63: 1010-1016.

Abrahams, M. V., and P. W. Colgan. 1985. Risk of predation, hydrodynamic efficiency and their influence on school structure. Environmental Biology of Fishes 13: 195-202.

Brown, J. A., P. H. Johansen, and P. W. Colgan. 1985. Subtle changes in the predator-avoidance behaviour of the guppy (Poecilia reticulata) after exposure to Pentachlorophenol. Canadian Journal of Zoology 63: 2001-2005.

Brown, J.A., and P. W. Colgan. 1985. Interspecific differences in the ontogeny of feeding behaviour in two species of centrarchid fish. Zeitschrift Fur Tierpsychologie 70: 70-80.

Brown, J. A., and P. W. Colgan. 1985. The ontogeny of social behaviour in four species of centrarchid fish. Behaviour 92: 254-276.

Johansen, P. H., A. R. Mathers, J. A Brown, and P. W. Colgan. 1985. Mortality of early life stages of largemouth bass juveniles due to pentachlorophenol exposure. Bulletin of Environmental Contamination and Toxicology 34: 377384.

Colgan, P. W., and A. B. Salmon. 1986. Breeding experience and parental behaviour in convict cichlads (Cichlasoma nigrofasciatum). Behavioural Processes 13: 101-118.

Colgan, P. W., J. A. Brown, and S. Orsatti. 1986. Role of diet and experience in the development of feeding behaviour in largemouth bass (Micropterus salmoides). Journal of Fisheries Biology 28: 161-170.

Brown, J. A., and P. W. Colgan. 1986. Individual and species recognition in centrarchid fishes: evidence and hypothesis. Behavioural Ecology and Sociobiology 19:373-379.

Colgan, P. W. 1986. The motivational basis of fish behaviour. Pages 23-46 in The behaviour of teleost fishes. Edited by T. J. Pitcher. Croom Helm, London.

Eadie, J. M., L. Broekhoven, and P. W. Colgan. 1986. Size ratios and artifacts: Hutchison's rule re-visited. American Naturalist 129: 1-17.

Johansen, P. H., A. R. Mathers, J. A. Brown, and P. W. Colgan. 1987. Growth of largemouth bass juveniles exposed to various concentrations of pentachlorophenol. Bulletin of Environmental Contamination and Toxicology 39: 379-384.

Abrahams, M. V., and P. W. Colgan. 1987. Fish schools and their hydrodynamic function: a reanalysis. Environmental Biology of Fishes 20: 79-80.

Gotceitas, V., and P. W. Colgan. 1987. Selection between densities of vegetation by young bluegill sunfish (Lapomis macrochirus) when avoiding predation. Transactions of American Fisheries Society 116: 40-49.

Morgan, M. J., and P. W. Colgan. 1987. The effects of predation presence and shoal size on foraging and bluntnose minnows, Pimephales notatus. Environmental Biology of Fishes 20: 105-111.

Orsatti, S. D., and P. W. Colgan. 1987. Effects of sulphuric acid exposure on the behaviour of largemouth bass,
Micropterus salmoides. Environmental Biology of Fishes 19: 119-129.

Brown, J. A., P. H. Johansen, P. W. Colgan, and A. R. Mathers. 1987. Exposure to Pentachlorophenol impairs the early feeding behaviour of largemouth bass (Micropterus salmoides). Transactions of the American Fisheries Society 116: 71-78.

Thompson, I. D., and P. W. Colgan. 1987. Numerical responses of martens to a food shortage in northcentral Ontario. Journal of Wildlife Management 51: 824-835.

Morgan, M. J., and P. W. Colgan. 1988. The role of experience in foraging shoals of bluntnose minnows (Pimephales notatus). Behavioural Processes 16: 87-94.

Colgan, P. W., and J. A. Brown.1988. Dynamics of nest defense of male centrarchid fish. Behavioural Processes 17: 17-26.

Gotceitas, V., and P. W. Colgan. 1988. Individual variation in learning by foraging juvenile bluegill sunfish (Lepomis macrochirus). Journal of Comparative Psychology 102: 294-299.

Gotceitas, V., and P. W. Colgan. 1989. Predator foraging success and habitat complexity: a quantitative test of the threshold hypothesis. Oecologia 80: 168-166.

Crawford, S. S., and P. W. Colgan. 1989. Motivational models of courtship in male three-spine sticklebacks Gasterosteus aculeatus. Behaviour 109: 285-302.

Jamieson, I. G., and P. W. Colgan. 1989. Eggs in the nests of males and their effect on mate choice in the three-spined stickleback. Animal Behaviour 38: 859-865.

Colgan, P. W., T. L. Jamieson, J. E. Frame, and J .T. Smith. 1990. Simulation Studies of Song Learning in Birds 281 in From animals to animats. Proceedings of the First International Conference on Simulation of Adaptive Behavior. Edited by Jean-Arcady Meyer and Stewart W. Wilson. The MIT Press: Cambridge, Massachusetts.

Gotceitas, V., and P. W. Colgan. 1990. The effects of prey availability and predation risk on habitat selection by juvenile bluegill sunfish. Copeia 1990: 407-409.

Gotceitas, V., and P. W. Colgan. 1990. Behavioural response of juvenile bluegill sunfish to variation in predation risk and food level. Ethology 85: 247-255.

Reebs, S. G., and P. W. Colgan. 1990. Nocturnal care of eggs and circadian rhythms of fanning activity in two normally diurnal cichlid fishes, Cichlasoma nigrofasciatum and Herotilapia multispinosa. Animal Behaviour 41: 303-311.

Gotceitas, V., and P. W. Colgan. 1991. Assessment of patch profitability and ideal free distribution: the significance of sampling. Behaviour 119: 65-76.

Colgan P., V. Gotceitas, and J. Frame. 1991. Individual variation, acquisition, and reacquisition in a foraging task by juvenile bluegill sunfish (Lepomis macrochirus). Journal of Comparative Psychology 105: 78-84.

Gabora, L., and P. Colgan. 1991. A model of the mechanisms underlying exploratory behavior. In From Animals to Animats: Proceedings of the First International Conference on Simulation of Adaptive Behavior. Edited by Jean-Arcady Meyer and Stewart W. Wilson. The MIT Press: Cambridge, Massachusetts.

Kieffer, J. D., and P. W. Colgan. 1991. Individual variation in learning by foraging pumpkinseed sunfish Lepomis gibbosis: the influence of habitat. Animal Behaviour 41: 603-612.

Lavery, R. J., and P. W. Colgan. 1991. Brood age and parental defence in the convict cichlid. Animal Behaviour 41: 945-952. 
Samis, A. J. W., P. W. Colgan, and P. H. Johansen. 1991. A comparison of the effects of subchronic and acute spillmimicking pentachlorophenol exposures on growth of bluegill sunfish (Lepomis macrochirus). Aquatic Toxicology 19: 231-240.

Thompson, I. D., and P. W. Colgan. 1991. Prey choice by marten during a decline in prey abundance. Oecologia 83: 443-451.

Langley, R. G., J. W. Driscoll, and P. W. Colgan. 1992. Diurnal rhythms of activity in three species of sunfish (Lepomis spp.) Journal of Interdisciplinary Cycle Research 24: 56-64.

Jamieson, I. G., and P. W. Colgan. 1992. Sneak spawning and egg stealing by male three-spine sticklebacks. Canadian Journal of Zoology 70: 963-967

Jamieson, I. G., D. M. Blouw, and P. W. Colgan. 1992. Parental care as a constraint on male matching success in fishes in a comparative study of threespine and white sticklebacks. Canadian Journal of Zoology 70: 956-962.

Jamieson, I. G, D. M. Blouw, and P. W. Colgan. 1992. Observations on the reproductive biology of a newly discovered stickleback Gasterosteous. Canadian Journal of Zoology 70: 1057-1063.

Kieffer, J. D., and P. W. Colgan. 1992. The role of learning in fish behaviour. Reviews in Fish Biology 2: 125-143.

Kieffer, J. D., and P. W. Colgan. 1992. Differences in learning by foraging juvenile pumpkinseed and bluegill sunfish in a structured habitat. Environmental Biology of Fishes 33: 359-366.

Reebs, S. G., and P. W. Colgan. 1992. Proximal cues for nocturnal egg care in convict cichlids, Cichlasoma nigrofasciatum. Animal Behaviour 43: 209-214.

Kieffer, J. D., and P. W. Colgan. 1993. Foraging flexibility in pumpkinseed (Lepomis gibbosus): Influence of habitat structure and prey type. Canadian Journal of Fisheries and Aquatic Sciences 50: 1699-1705.

Waas, J. R., and P. W. Colgan. 1993. Chemical cues associated with the visually elaborate aggressive displays of three-spine sticklebacks. Journal of Chemical Ecology 18: 2277-2284.

Thompson, I. D., and P. W. Colgan. 1994. Marten activity in uncut and logged boreal forests in Ontario. Journal of Wildlife Management 58: 280-288.

Waas, J. R., and P. W. Colgan. 1994. Male sticklebacks can distinguish between familiar rivals on the basis of visual cues alone. Animal Behaviour 47: 7-13.

Samis, A. J. W., P. W. Colgan, and P. H. Johansen. 1995. Recovery from the effects of subchronic pentachlorophenol exposure on growth of juvenile bluegill sunfish (Lepomis macrochirus). Canadian Journal of Zoology 72: 1993-1977.

Waas, J. R., M. Caulfield, P. W. Colgan, and P. T. Boag. 2000. Colony sound facilitates sex and agonistic activities in royal penguins. Animal Behaviour 60: 77-84.

Book Reviews from 1978-2004 [reviews after 1997 were incompletely recorded in Patrick's files, but those in the Canadian Field-Naturalist and the Book Review Annual for 1998-2004 were compiled and added by F. R. Cook. from these publications.]

Colgan, P. 1978. Review of R. Dawkins: The Selfish Gene. Environmental Biology of Fishes 3: 327-328.

Colgan, P. 1980. Review of E. S. Reese and F. J. Lighter (Editors): Contrasts in Behaviour. Behavioural Processes 5: $81-82$
Colgan, P. 1980. Review of D. Mostofsky (Editor): The Behavior of Fish and Other Aquatic Organisms. Behavioural Processes 5: 82-83.

Colgan, P. 1981. Review of M. D. Zeiler and R. Harzem (Editors): Reinforcement and the Organization of Behaviour. Behavioural Processes 6: 96-97.

Colgan, P. 1981. Review of R. Cattell: The Scientific use of Factor Analysis in Behavioural and Life Sciences. Behavioural Processes 6: 385-386.

Colgan, P. 1981. Review of J. T. Bonner: The Evolution of Culture in Animals. Canadian Field-Naturalist 95: 221222.

Colgan, P. 1982. Review of F. Toates: Animal Behaviour A Systems Approach. Behavioural Processes 7: 189-190.

Colgan, P. 1982. Review of D. M. Broom: Biology of Behaviour. Quarterly Review of Biology 57: 488.

Colgan, P. 1983. Review of W. N. Tavolga, A. N. Popper, and A. A. Fay (Editors): Hearing and Sound Communication in Fishes. Behavioural Processes 8: 205-206.

Colgan, P. 1983. Review of P. W. Witt and J. S. Rovner (Editors): Spider Communication. Canadian Field Naturalist 97: 246.

Colgan, P. 1983. Review of K. P. Burnham et al.: Estimation of Density from Line Transect Sampling of Biological Populations. Canadian Field-Naturalist 97: 246.

Colgan, P. 1983. Review of F. O. Pinto and B. W. Conolly (Editors): Applicable Mathematics of Non-physical Phenomena. Quarterly Review of Biology 58: 312.

Colgan, P. 1984. Review of C. J. Barnard: Animal Behaviour, Ecology and Evolution. Behavioural Processes 9: 103.

Colgan, P. 1984. Review of G. Davey (Editor): Animal Models of Human Behaviour. Behavioural Processes 9: 104-105.

Colgan, P. 1984. Review of J. Gould: Ethology. Queen's Quarterly 91: 202-204.

Colgan, P. 1985. Review of P. P. G. Bateson and P. M. Klopfer (Editors): Perspectives in Ethology. Volume 5 Ontogeny. Behavioural Processes 10: 206-207.

Colgan, P. 1985. Review of R. Payne: (Editor): Communication and Behavior of Whales. Canadian Field-Naturalist 99: 276

Colgan, P. 1985. Review of R. Jellis: Bird Sounds and Their Meaning. Canadian Field-Naturalist 99: 282.

Colgan, P. 1985. Review of G. L. Wood: The Guinness Book of Animal Facts and Feats. Canadian Field-Naturalist 99: 283.

Colgan, P. 1985. Review of J. R. Krebs and N. B. Davies (Editors): Behavioural Ecology: An Evolutionary Approach. Canadian Field-Naturalist 99: 455-456.

Colgan, P. 1985. Review of R. R. Baker's Bird Migration: The Solution of a Mystery? Canadian Field-Naturalist 99: 457-458.

Colgan, P. 1986. Review of M. Ridley: The Explanation of Organic Diversity: The comparative method and adaptations for mating. Behavioural Processes 11: 220-221.

Colgan, P. 1986. Review of R. M. Sibly and R. H. Smith (Editors): Behavioural Ecology. Bioscience 36: 682-683.

Colgan, P. 1986. Review of H. Schone: Spatial orientation. Canadian Field-Naturalist 100: 295.

Colgan, P. 1986. Review of R. I. M. Dunbar: Reproductive Decisions. Canadian Field-Naturalist 100: 295.

Colgan, P. 1986. Review of B. Holldobler and M. Lindauer (Editors): Experimental Behavioural Ecology and Sociobiology. Canadian Field-Naturalist 100: 444. 
Colgan, P. 1986. Reviews of P. Kitcher: Vaulting Ambition; S. Rose et al.: Not in Our Genes; J. Q. Wilson and R. J. Herrnstein: Crime and Human Nature. Queen's Quarterly 93: 595-612.

Colgan, P. 1987. Review of P. Martin and P. Bateson (Editors): Measuring Behaviour - An introductory Study Guide. Behavioural Processes 15: 347-349.

Colgan, P. 1987. Review of P. J. B. Slater: An Introduction to Ethology. Canadian Field-Naturalist 101: 497.

Colgan, P. 1987. Review of M. E. Feder and G. V. Lauder (Editors): Predator prey relationships: Perspectives and approaches from the study of lower vertebrates. Canadian Field-Naturalist 101: 504-505.

Colgan, P. 1987. Review of J. A. Endler: Natural Selection in the Wild. Canadian Field-Naturalist 101: 508 - 509.

Colgan, P. 1987. Review of A. C. Kamil et al. (Editors): Foraging Behavior. Quarterly Review of Biology 63: 122.

Colgan, P. 1987. Review of H. J. V. Nossal: Reshaping Life. Queen's Quarterly 93: 938-940.

Colgan, P. 1988. Review of D. I. Rubenstein and R. W. Wrangham (Editor): Ecological Aspects of Social Evolution Birds and Mammals. Canadian Field-Naturalist 102: 177-179.

Colgan, P. 1988. Review of R. J. Hoage and L. Goldman: Animal Intelligence. Canadian Field-Naturalist 102: 589590.

Colgan, P. 1988. Review of J. R. Krebs and N. B. Davies: An Introduction to Behavioural Ecology. Canadian FieldNaturalist 102: 590-591.

Colgan, P. 1988. Review of P. J. B. Slater (Editor): The Encyclopedia of Animal Behavior. Canadian Field-Naturalist 102: 591.

Colgan, P. 1988. Review of J. L. Brown: Helping and Communal Breeding in Birds: Ecology and Evolution. Canadian Field-Naturalist 102: 749-750.

Colgan, P. 1988. Review of D. W. Stephens and J. R. Kreb: Foraging Theory. Canadian Field-Naturalist 102: 750-751.

Colgan, P. 1988. Review of D. Sharpe: Rochdale. Queen's Quarterly 95: 715-716.

Colgan, P. 1988. Review of D. Suzuki: Metamorphosis. Queen's Quarterly 95: 753-754.

Colgan, P. 1988. Review of R. Augros and G. Stanciu: The New Biology. Queen's Quarterly 95: 945-947.

Colgan, P. 1989. Review of W. Koenig and R. L. Mumm: Population Ecology of the Cooperatively Breeding Acorn Woodpecker. Canadian Field-Naturalist 103: 109-110.

Colgan, P. 1989. Review of A. T. Bergerud and M. W. Gratson: Adaptive Strategies and Population Ecology of Northern Grouse. Canadian Field-Naturalist 103: 450-451.

Colgan, P. 1989. Review of C. Meine: Aldo Leopold. Canadian Field-Naturalist 103: 467-468.

Colgan, P. 1989. Review of T. Seddon: Animal Vision. Canadian Field-Naturalist 103: 473.

Colgan, P. 1989. Review of J. Bailey: Mimicry and Camouflage. Canadian Field-Naturalist 103: 473.

Colgan, P. 1989. Review of B. D. C. Sade and Z. T. Halpin (Editors): Mammalian Dispersal Patterns. Canadian FieldNaturalist 103: 616-617.

Colgan, P. 1990. Review of P. P. G. Bateson and P. H. Klopfer (Editors): Perspectives in Ethology Volume 8. Bioscience 40: 148-149.

Colgan, P. 1990. Review of J. Alcock: The Kookaburras' Song. Canadian Field-Naturalist 103: 618.

Colgan, P. 1990. Review of L. Brown and J. Downhower: Analyses in Behavioural Ecology. Canadian Field-Naturalist 104: 150-151.
Colgan, P. 1990. Review of T. H. Waterman: Animal Navigation. Canadian Field-Naturalist 104: 331-332.

Colgan, P. 1990. Review of D. Morse: American Warblers. Canadian Field-Naturalist 104: 502.

Colgan, P. 1990. Review of P. Anderson: Dispersal in Rodents: A Resident Fitness Hypothesis. Canadian Field-Naturalist 104: 503-504.

Colgan, P. 1990. Review of T. Seddon: Animal Parenting. Canadian Field-Naturalist 104: 515.

Colgan, P. 1991. Review of J. P. Rauschecker and P. Marler (Editors): Imprinting and Cortical Plasticity: Comparative Aspects of Sensitive Periods. Behavioural Processes 23: 153-155.

Colgan, P. 1991. Review of D.A. Dewsbury (Editor): Studying Animal Behavior. Canadian Field-Naturalist 105: 309_ 310.

Colgan, P. 1991. Review of S. B. Vanderwall: Food Hoarding in Animals. Canadian Field-Naturalist 105: 438.

Colgan, P. 1991. Review of R. Burton's Bird Flight. Canadian Field-Naturalist 105: 604.

Colgan, P. 1991. Review of G. Weissmann: The Doctor with Two Heads. Queen's Quarterly 98: 248-249.

Colgan, P., and I. Jamieson. 1991. Review of M. Clark: The Optimization Approach to Behavior. Behaviourial and Brain Sciences 14: 95-96.

Colgan, P. 1991. Review of J. A. Burnett, C. T. Dauphiné, S. H. McCrindle, and T. Mosquin: On the Brink: Endangered Species in Canada. Canadian Biodiversity 1(3): 4849.

Colgan, P. 1992. Review of P. W. Dowrick (Editor): Practical Guide to Using Video in the Behavioral Sciences. Behavioural Processes 26: 59-60.

Colgan, P. 1992. Review of P. P. G. Bateson and P. H. Klopfer (Editors): Perspectives in Ethology Volume 9. Human Understanding and Animal Awareness. Behavioural Processes 26: 60-61.

Colgan, P. 1992. Review of R. M. Hughes (Editor): Behavioural Mechanisms of Food Selection. Behavioural Processes 27: 151-152.

Colgan, P. 1992. Review of B. Kramer's Electrocommunication in Teleost Fishes. Behavioural Processes 27: 152153.

Colgan, P. 1992. Review of T. A. Sebeok: A Sign is Just a Sign. Behavioural Processes 27: 219.

Colgan, P. 1992. Review of D. H. Meadows, D. L. Meadows, and J. Randers: Beyond the Limits. Canadian Biodiversity 2(3): 52-53.

Colgan, P. 1992. Review of A. M. Wenner and P. H. Wells: Anatomy of a Controversy. Canadian Field-Naturalist 106: 154.

Colgan, P. 1992. Review of M. Bekoff and D. Jamieson (Editor): Interpretation and Explanation in the Study of Animal Behavior. Canadian Field-Naturalist 106: 157-158.

Colgan, P. 1992. Review of D. R. Brooks and D. A. McLennan: Phylogeny, Ecology, and Behavior. Canadian FieldNaturalist 106: 279-280.

Colgan, P. 1992. Review of T. H. C. Brock: The Evolution of Parental Care. Canadian Field-Naturalist 106: 279.

Colgan, P. 1992. Review of S. T. Parker and K. R. Gibson (Editors): "Language" and intelligence in monkeys and apes. Canadian Field-Naturalist 106: 285-286.

Colgan, P. 1992. Review of P. B. Sanders: Carl Akeley. Canadian Field-Naturalist 106: 298.

Colgan, P. 1992. Review of R. A. Croker: Pioneer Ecologist The Life and Work of Victor Ernest Shelford. Canadian Field-Naturalist 106: 422. 
Colgan, P. 1992. Review of T. Heuss: Anton Dohrn A Life for Science. Canadian Field-Naturalist 106: 550.

Colgan, P. 1993. Review of J. Vauclair: L 'intelligence de l'animal. Behavioural Processes 29: 162.

Colgan, P. 1993. Review of P. Haccou and E. Meelis: Statistical Analysis of Behavioural Data. Behavioural Processes 29: 163

Colgan, P. 1993. Review of P.K. McGregor: Playback and Studies of Animal Communication. Behavioural Processes 30: $87-88$.

Colgan, P. 1993. Review of J. Foster et al. (Editors) Buffalo. Canadian Book Review Annual: 491-492.

Colgan, P. 1993. Review of E. Claridge and B. A. Miligan: Animal Signatures. Canadian Book Review Annual: 492493.

Colgan, P. 1993. Review of E. Hoyt: Riding with the Dolphins. Canadian Book Review Annual: 495.

Colgan, P. 1993. Review of Peterborough Field Naturalists: Kawarthas Nature. Canadian Book Review Annual: 496497.

Colgan, P. 1993. Review of W. Barrett and G. Saunders: Wildlife of Atlantic Canada and New England. Canadian Book Review Annual: 500.

Colgan, P. 1993. Review of L. Labatt and B. Littlejohn: Islands of Hope. Canadian Book Review Annual: 504-505.

Colgan, P. 1993. Review of F. Gregory: Nature lost? Canadian Field-Naturalist 107: 135.

Colgan, P. 1993. Review of D. R. Giffin: Animal Minds. Canadian Field-Naturalist 107: 258-259.

Colgan, P. 1993. Review of G. B. Goode: The Origins of Natural Science in America. Canadian Field-Naturalist 107: 262.

Colgan, P. 1993. Review of I. Tree: The Ruling Passion of John Gould. Canadian Field-Naturalist 107: 389.

Colgan, P. 1993. Review of E. C. Hargrove: The Animal Rights/Environmental Ethics Debate. Canadian FieldNaturalist 107: 557.

Colgan, P. 1994. Review of R. Stoltmann: Written by the Wind. Canadian Book Review Annual: 1073.

Colgan, P. 1994. Review of N. Evernden: The Natural Alien. Canadian Book Review Annual: 2127.

Colgan, P. 1994. Review of F. Bruemmer: The Narwhal. Canadian Book Review Annual: 5002.

Colgan, P. 1994. Review of D. W. Nagorsen and R. M. Brigham: Bats of British Columbia. Canadian Book Review Annual: 5011.

Colgan, P. 1994. Review of B. Obee: Canadian Wildlife. Canadian Book Review Annual: 5013.

Colgan, P. 1994. Review of S. H. Paine: Beachwalker Sea Life of the West Coast. Canadian Book Review Annual: 5014

Colgan, P. 1994. Review of D. Sanders and D. Swanson: The Emerald Sea. Canadian Book Review Annual: 5018.

Colgan, P. 1994. Review of D. A. E. Spalding: Dinosaur Hunters. Canadian Book Review Annual: 5019.

Colgan, P. 1994. Review of J. B. Stelfox: Hoofed Mammals of Alberta. Canadian Book Review Annual: 5020.

Colgan, P. 1994. Review of D. Swanson: Why Seals Blow their Noses. Canadian Book Review Annual: 6307.

Colgan, P. 1994. Review of A. Morton: In the Company of Whales. Canadian Book Review Annual: 6302.

Colgan, P. 1994. Review of P. B. Moyle: Fish for Enthusiast's Guide. Canadian Field-Naturalist 108: 261.

Colgan, P. 1994. Review of P. A. Johnsgard: Arena Birds. Canadian Field-Naturalist 108: 386-387.
Colgan, P. 1994. Review of M. A. Ali (Editor): Rhythms in Fishes. Canadian Field-Naturalist 108: 502.

Colgan, P. 1994. Review of T. Halliday (Editor): Animal Behavior. Canadian Field-Naturalist 108: 503.

Colgan, P. 1995. Review of R. V. Short and E. Balaban (Editors): The Differences between the Sexes. Behavioural Proceedings 34: 103-104.

Colgan, P. 1995. Review of M. Newman: Life in a Fishbowl. Canadian Book Review Annual: 2072.

Colgan, P. 1995. Review of P. Watson: Ocean Warrior. Canadian Book Review Annual: 2097.

Colgan, P. 1995. Review of K. E. Von Maltzahn: Nature as Landscape. Canadian Book Review Annual: 4230.

Colgan, P. 1995. Review of W. Grady: Coyotes. Canadian Book Review Annual: 5002.

Colgan, P. 1995. Review of P. Kochanoff: Nearby Nature. Canadian Book Review Annual: 5006.

Colgan, P. 1995. Review of R. Ludvigsen and G. Beard: West Coast Fossils. Canadian Book Review Annual: 5008.

Colgan, P. 1995. Review of B. Obee: Wolf. Canadian Book Review Annual: 5013.

Colgan, P. 1995. Review of C. Russell: Spirit Bear. Canadian Book Review Annual: 5014.

Colgan, P. 1995. Review of H. Thurston: Dawning of the Dinosaurs. Canadian Book Review Annual: 5015.

Colgan, P. 1995. Review of R. Busch: Wolf Songs. Canadian Book Review Annual: 5016.

Colgan, P. 1995. Review of D. Wood: Wolves. Canadian Book Review Annual: 5017.

Colgan, P. 1995. Review of A. Carr: A Naturalist in Florida. Canadian Field-Naturalist 109: 141.

Colgan, P. 1995. Review of L.A. Real (Editor): Behavioral Mechanisms in Evolutionary Ecology. Canadian FieldNaturalist 109: 490-491.

Colgan, P. 1995. Review of D. Lindsay: Science in the Subarctic. Canadian Field-Naturalist 109: 512-513.

Colgan, P. 1995. Review of E. Sober: From a Logical Point of View. Canadian Field-Naturalist 109: 514.

Colgan, P. 1996. Review of D. J. Depew and B. M. Weber: Darwinism Evolving. Canadian Field-Naturalist 109: 515.

Colgan, P. 1995. Review of L. S. Hamilton (Editor): Ethics Religion and Biodiversity: Relations between Conservation and Cultural Values. Global Biodiversity 5(2): 46-47.

Colgan, P. 1995. Review of L. Grande and O. Rieppel (Editors): Interpreting the Hierarchy of Nature. From Systematic Patterns to Evolutionary Process Theories. Global Biodiversity 5(3): 39 .

Colgan, P. 1995. Review of P. S. Cato and C. Jones (Editors): Natural History Museums Directions for Growth. Natural History Conservation 9: 5.

Colgan, P. 1995. Review of Recent Setbacks in Conservation. Natural History Conservation 9: 5.

Colgan, P. 1995. Review of J. H. Schroder and al.: Trends in Ichthyology. Reviews of Fish Biology and Fisheries 5: 258-259.

Colgan, P. 1996. Review of N. S. Thompson (Editor): Perspectives in Ethology. II Behavioural Design. Behaviour Processes 37: $251-252$.

Colgan, P. 1996. Review of J. A. Hogan and J. J. Bolhuis (Editors): Causal Mechanisms of Behavioural Development. Behavioural Processes 37: 253-254.

Colgan, P. 1996. Review of R. Wong (Editor): Biological Perspectives on Motivated Activities. Behavioural Processes 37: 265-266. 
Colgan, P. 1996. Review of B. J. Christie: The Horses of Sable Island. Canadian Book Review Annual: 5002.

Colgan, P. 1996. Review of R. L. Grambo: The Nature of Foxes. Canadian Book Review Annual: 5007.

Colgan, P. 1996. Review of S. H. Paine: The Nature of Arctic Whales. Canadian Book Review Annual: 5013.

Colgan, P. 1996. Review of G. Parker: Eastern Coyote. Canadian Book Review Annual: 5014.

Colgan, P. 1996. Review of F. Stewart (Editor): The Presence of Whales. Canadian Book Review Annual: 5016.

Colgan, P. 1996. Review of K. Scott: Hiking in Bear Country. Canadian Book Review Annual: 5018.

Colgan, P. 1996. Review of M. Snyderman: Shark. Canadian Book Review Annual: 5020

Colgan, P. 1996. Review of D. Thomas and M. Enns: Grizzly Kingdom. Canadian Book Review Annual: 5021.

Colgan, P. 1996. Review of M. Matthen and R. X. Ware (Editors): Biology and Society. Canadian Book Review Annual: 5043 .

Colgan, P. 1996. Review of T. Everts and B. Kalman: Really Weird Animals. Canadian Book Review Annual: 6310.

Colgan, P. 1996. Review of E. S. Grace: Apes. Canadian Book Review Annual: 6314.

Colgan, P. 1996. Review of B. Kalman: Penguins. Canadian Book Review Annual: 6318.

Colgan, P. 1996. Review of W. Lynch: Bears Bears Bears. Canadian Book Review Annual: 6322.

Colgan, P. 1996. Review of A. Mason: Oceans. Canadian Book Review Annual: 6324.

Colgan, P. 1996. Review of D. Swanson: Sky Dancers. Canadian Book Review Annual: 6335.

Colgan, P. 1996. Review of M. Ruse: Evolutionary Naturalism. Canadian Field-Naturalist 110: 568.

Colgan, P. 1996. Review of S. R. Kellert: The Value of Life: Biological Diversity and Human Existence. Global Biodiversity 6(3): 43-44.

Colgan, P. 1996. Review of B. G. Nortonsea Cumb et al. (Editors): Ethics on the Ark: Zoos, Animal Welfare, and Wildlife Conservaion. Global Biodiversity 6(2): 44.

Colgan, P. 1996. Review of J. N. Thompson: The Coevolutionary Process. Global Biodiversity 6(2): 44-45.

Colgan, P. 1997. Review of D. Takacs: The Idea of Biodiversity: Philosophies of Paradise. Global Biodiversity 7(1): 46.

Colgan, P. 1997. Review of Animal Cognition: An Introduction to Modern Comparative Osycology 41: 292.

Colgan, P. 1997. Review of K. Lorenz: The Natural Science of the Human Species. Behavioural Processes 41: 211.

Colgan, P. 1997. Review of M. Dol et al. (Editor): Animal Consciousness and Animal Ethics. Behavioural Processes 41: 211-212.

Colgan, P. 1997. Review of E. Bauer: Bears: Behavior, Ecology, Conservation. Canadian Book Review Annual: 2004

Colgan, P. 1997. Review of J. S. Bleakney: Sea Slugs of Atlantic Canada and the Gulf of Mexico. Canadian Book Review Annual: 5005.

Colgan, P. 1997. Review of R. Cannings and S. Cannings: British Columbia: A Natural History. Canadian Book Review Annual: 5007.

Colgan, P. 1997. Review of D. Dekker: Wolves in the Rocky Mountains from Jasper to Yellowstone. Canadian Book Review Annual: 5012.

Colgan, P. 1997. Review of R. Orenstein (Editor): Elephants: The Deciding Decade. Canadian Book Review Annual: 5013.
Colgan, P. 1997. Review of R. M. Harbo: Shells and Shellfish of the Pacific Northwest. Canadian Book Review Annual: 5017.

Colgan, P. 1997. Review of P. Lambert: Sea Cucumbers of British Columbia, Southeast Alaska and Puget Sound. Canadian Book Review Annual: 5020.

Colgan, P. 1997. Review of I. McAlister, K. McAlister, and C. Young: The Great Bear Rainforest: Canada's Forgotten Coast. Canadian Book Review Annual: 5023.

Colgan, P. 1997. Review of W. R. Pollard et al.: Field Identification of Juvenile Salmonids. Canadian Book Review Annual: 5028.

Colgan, P. 1997. Review of B. Hodgrove (Editor): The Rat: A Perverse Miscellany. Canadian Book Review Annual: 05029.

Colgan, P. 1997. Review of R. Careless: To Save the Wild Earth. Canadian Book Review Annual: 05037.

Colgan, P. 1997. Review of H. T. Epp (Editor): Ecological Reclamation in Canada at Century's Turn. Canadian Book Review Annual: 05038.

Colgan, P. 1997. Review of M. Keating: Canada and the State of the Planet: The Social, Economic, and Environmental Trends that are Shaping our Times. Canadian Book Review Annual: 05039.

Colgan, P. 1997. Review of V. Shiva: Biopiracy: The Plunder of Nature and Knowledge. Canadian Book Review Annual: 5040

Colgan, P. 1997. Reviews of D. Hodge: Whales; Wild Dogs. Canadian Book Review Annual: 6363, 6364.

Colgan, P. 1997. Reviews of B. Kalman: Why Do Animals Do That? How Animals Communicate? Canadian Book Review Annual: 6368, 6369.

Colgan, P. 1997. Review of P. J. Stoett: The International Politics of Whaling. Canadian Book Review Annual: 5048.

Colgan, P. 1997. Reviews of D. Swanson: Bears; Otters. Canadian Book Review Annual: 6383,6384.

Colgan, P. 1997. Review of C. K. Catchpole and P. J. B. Slater: Bird Song. Canadian Field-Naturalist 111: 348.

Colgan, P. 1997. Review of R. Dawkins: River out of Eden. Canadian Field-Naturalist 111: 354.

Colgan, P. 1998. Review of B. and R. Mearns: The Bird Collectors. Canadian Field-Naturalist 112: 574.

Colgan, P. 1998. Review of T. Wilkins: John Muir: Apostle of Nature. Canadian Field-Naturalist 112: 754.

Colgan, P. 1998. Review of L. Spalding: The Follow: A True Story. Canadian Book Review Annual: 2090.

Colgan, P. 1998. Review of W. Davis: The Clouded Leopard: Travels to Landscapes of Spirit and Desire. Canadian Book Review Annual: 4191.

Colgan, P. 1998. Review of D. Suzuki: Earth Time. Canadian Book Review Annual: 4256.

Colgan, P. 1998. Review of F. Bruemmer: Seals in the Wild. Canadian Book Review: Annual 5002.

Colgan, P. 1998. Review of W. Bush: Ascent of Dogs: Working Dogs in the West. Canadian Book Review Annual: 5004.

Colgan, P. 1998. Review of D. Gilroy: Out and About: Fifty Years of Wildlife Watching. Canadian Book Review Annual: 5014.

Colgan, P. 1998. Review of R. D. Lawrence: Paddy: The Classic story of a Baby Beaver and the Naturalist Who Adopted Him. Canadian Book Review Annual: 5024.

Colgan, P. 1998. Review of R. D. Lawrence: The Place in the Forest. Canadian Book Review Annual: 5025. 
Colgan, P. 1998. Review of G. MacEwan: Memory Meadows: Horse Stories from Canada's Past. Canadian Book Review Annual: 5028.

Colgan, P. 1998. Review of G. MacMillan: A Breed Apart: Nova Scotia's Duck Tolling Retriever. Canadian Book Review Annual: 5029.

Colgan, P. 1998. Review of G. Parker: The Eastern Panther: Mighty Cat of the Appalachians. Canadian Book Review Annual: 5030.

Colgan, P. 1998. Review of L. Scanlan: Wild About Horses: Our Timeless Passion for the Horse. Canadian Book Review Annual: 5032.

Colgan, P. 1998. Review of B. Silliker, Jr.: Moose: Giant of the Northern Forest. Canadian Book Review Annual: 5035.

Colgan, P. 1998. Review of K. Van Tighem: Coming West: A Natural History of Home. Canadian Book Review Annual: 5039 .

Colgan, P. 1998. Review of G. B.Wiggins: A Cadesfly Family Phryganeidae (Trichoptera). Canadian Book Review Annual: 5040 .

Colgan, P. 1998. Review of A. Frizzell and N. H. Pammett: Shades of Green: Environmental Attitudes in Canada and around the World. Canadian Book Review Annual: 5043.

Colgan, P. 1998. Review of M. Harris: Lament for an Ocean: the Collapse of the Atlantic Cod Industry - A True Crime Story. Canadian Book Review Annual: 5048.

Colgan, P. 1998. Review of B. Parfitt: Forest Follies. Canadian Book Review Annual: 5053.

Colgan, P. 1998. Review of J. B. Cruxton: Discovering the Amazon Rainforest: 6365.

Colgan, P. 1998. Review of S. Funston: Animal Smarts. Canadian Book Review Annual: 6369.

Colgan, P. 1998. Review of A. Holden-Boone: Coral Reef. Canadian Book Review Annual: 6375.

Colgan, P. 1998. Reviews of B. Kalman and J. Langille: What are Food Chains and Webs? What is a Life Cycle? Canadian Book Review Annual: 6382, 6383. Review Annual: 5011.

Colgan, P. 1999. Review of R. D. Lawrence: Where the Water Lilies Grow. Canadian Book Review Annual: 5013.

Colgan, P. 1999. Review of C. White: Living off the Sea. Canadian Book Review Annual: 5029.

Colgan, P. 1999. Review of K. Drushka: In the Bight: The B.C. Forest Industry Today. Canadian Book Review Annual: 5038 .

Colgan, P. 1999. Review of F. L. Bunnell and J. F. Jonson (Editors): Policy and Practice for Biodiversity in Managed Forests: The Living Dance. Canadian Book Review Annual: 5049

Colgan, P. 1999. Review of C. Tollefson (Editor): The Wealth of Forests: Markets, Regulation, and Sustainable Forestry. 5052 .

Colgan, P. 1999. Review of J. Wilson: Talk and Log: Wilderness Politics In British Columbia 1965-1996. Canadian Book Review Annual: 5053.

Colgan, P. 1999. Review of D. M. Hayne (Editor): Human Survivability in the $21^{\text {st }}$ Century. Canadian Book Review Annual: 5067.

Colgan, P. 1999. Review of F. Wilson: The Logic and Methodology of Science in Early Modern Thought. Canadian Book Review Annual: 5070.

Colgan, P. 2000. Review of L. Dugatkin: Cheating Monkeys and Citizen Bees. Canadian Field-Naturalist 114: 169.

Colgan, P. 2000. Review of R. Dukas (Editor): Cognitive Ecology. Canadian Field-Naturalist 114: 344-345.
Colgan, P. 2000. Review of A. I. Houston and J. M. McNamara: Methods of Adaptive Behaviour. Canadian FieldNaturalist 114: 541.

Colgan, P. 2000. Review of P. Turchin: Quantitative Analysis of Movement. Canadian Field-Naturalist 114: 547-548.

Colgan, P. 2000. Review of J. Terborgh: Requiem for Nature. Canadian Field-Naturalist 114: 722.

Colgan, P. 2000. Review of A. A. Gilpin and P. PatchetGoluber: A Guide to Writing in the Sciences. Canadian Book Review Annual: 1016.

Colgan, P. 2000. Review of C. Montgomery: Brood Relations: Animals, Humans, and Politics, Annual Book Review Annual 2139.

Colgan, P. 2000. Review of H. Brody: Seasons of the Arctic. Canadian Book Review Annual: 2171.

Colgan, P. 2000. Review of G. B. Doern and T. Reed (Editors): Risky Business: Canada's Changing Science-based Policy and Regulation Regime. Canadian Book Review Annual: 4061.

Colgan, P. 2000. Review of T. Glavin: The Last Great Sea. Canadian Book Review Annual: 5011.

Colgan, P. 2000. Review of H. Tammemagi: The Waste Crises: Landfills, Incinerators, and the Search for a Sustainable Future. Canadian Book Review Annual: 5042.

Colgan, P. 2000. Review of G. G. Beck and B. Littlejohn (Editors): Voices for the Water: Environmental Issues in the Great Lakes - St. Lawrence Drainage Basin. Canadian Book Review Annual: 5043.

Colgan, P. 2000. Review of P. M. Wood: Biodiversity and Democracy: Rethinking Society and Nature. Canadian Book Review Annual: 5045.

Colgan, P. 2000. Review of J. Bachler: Petrotyranny. Canadian Book Review Annual: 5046.

Colgan, P. 2000. Review of A. H. Perera, D. L. Euler, and I. D. Thompson (Editors): Ecology of a Managed Terrestrial Landscape: Patterns and Processes of Forest Landscapes in Ontario. Canadian Book Review Annual: 5047.

Colgan, P. 2000. Review of G. Hak: Turning Trees into Dollars: The British Columbia Coastal Lumber Industry 18581913. Canadian Book Review Annual: 5048.

Colgan, P. 2000. Review of R. Hayter: Flexible Crossroads: The restructuring of British Columbia's Forest Economy. Canadian Book Review Annual: 5049.

Colgan, P. 2000. Review of B. O'Keefe and J. Macdonald: The Sommers Scandal: The Felling of Trees and Tree Lords. Canadian Book Review Annual: 5051.

Colgan, P. 2000. Review of L. A. Sandberg and P. Clancy: Against the Grain: Foresters and Politics in Nova Scotia, Canadian Book Review Annual: 5052.

Colgan, P. 2000. Review of A. McHughen: Pandora's Picnic Basket: The Potential and Hazards of Genetically Modified Foods. Canadian Book Review Annual: 5062.

Colgan, P. 2000. Review of D. M. Hayne (Editor): Governance in the $21^{\text {st }}$ Century: Proceedings of a Symposium held in November 1999 under the auspices of the Royal Society of Canada. Canadian Book Review Annual: 5068.

Colgan, P. 2001. Review of L. Taccon: Biodiversity and Ecological Economics: Participation Values and Resource Management. Biodiversity: Journal of Life on Earth 2(2): 37-38.

Colgan, P. 2001. Review of Atlantic Geoscience Society: The Last Billion Years; a Geological History of the Maritime Provinces of Canada. Canadian Book Review Annual: 5004. 
Colgan, P. 2001. Review of A. Gaal: In Search of Ogopogo: Sacred Creature of the Okanagan Waters. Canadian Book Review Review Annual: 5011.

Colgan, P. 2001. Review of W. Grady: The Bone Museum: Travels in the Lost World of Dinosaurs and Birds. Canadian Book Review Annual: 5012.

Colgan, P. 2001. Reviews of T. Hartson: Whales and Other Marine Mammals of British Columbia and Alaska; Whales of Oregon and Other Marine Mammals of Washington and Oregon. Canadian Book Review Annual: 5014, 5015.

Colgan, P. 2001. Review of L. Scanlon: Little Horse of Iron: a Quest for the Canadian Horse. Canadian Book Review Annual: 5023.

Colgan, P. 2001. Review of J. Billinghurst (Editor): The Spirit of the Whale: Legend, History, Conservation. Canadian Book Review Annual: 5027.

Colgan, P. 2001. Review of J. Bohlen: Making Waves: The Origins and Future of Greenpeace. Canadian Book Review Annual: 5028.

Colgan, P. 2001. Review of L. Jones (Editor): Global Warming: A Guide to the Science. Canadian Book Review Annual: 5029.

Colgan, P. 2001. Review of C. Potvin, M. Kraenzel, and G. Seutin (Editors): Protecting Biological Diversity Roles and Responsibilities. Canadian Book Review Annual: 5032.

Colgan, P. 2001. Review of D. Suzuki and H. Dessel: Good News for a Change: Hope for a Troubled Planet. Canadian Book Review Annual: 5033.

Colgan, P. 2001. Review of K. A. Armson: Ontario Forests: A Historical Perspective. Canadian Book Review Annual: 5034 .

Colgan, P. 2001. Review of D. Greer: Coming Through Fire: The Wildland Firefighter Experience. Canadian Book Review Annual: 5038.

Colgan, P. 2001. Review of P. W. B. Phillips and R. Wolfe (Editors): Govern My Food: Science, Safety, and Trade. Canadian Book Review Annual: 5067,

Colgan, P. 2001. Review of P. Demers (Editor): Science and Ethics/La science et l'éthique. Canadian Book Review Annual: 5069.

Colgan, P. 2002. Review of P. S. Chasek: The Global Environment in the Twenty-first Century: Prospects for International Cooperation. Canadian Field-Naturalist 116: 345.

Colgan, P. 2002. Review of J. Perry: Food for Thought: Catholic Insights into Modified Food. Canadian Book Review Annual: 2157.

Colgan, P. 2002. Review of P. Berton: Cats I Have Known and Loved. Canadian Book Review Annual: 5001.

Colgan, P. 2002. Review of N. Eyles: Ontario Rocks: Three Billion Years of Environmental Change. Canadian Book Review Annual: 5005.

Colgan, P. 2002. Review of G. MacEwan: Our Equine Friends: Stories of Horses in History. Canadian Book Review Annual: 5020.

Colgan, P. 2002. Review of R. Orenstein: Survivors in Armor: Turtles, Tortoises, and Terrapins. Canadian Book Review Annual: 5023.

Colgan, P. 2002. Review of J. D. Sept: The Beachcombers Guide to Seashore Life in California. Canadian Book Review Annual: 5027.

Colgan, P. 2002. Review of K. Beazley and J. Boardman: Politics of the Wild: Canada and Endangered Species. Canadian Book Review Annual: 5030.
Colgan, P. 2002. Review of D. L. VanNijnatten and R. Boardman (Editors): Canadian Environmental Policy: Context and Cases.Second edition. Canadian Book Review Annual: 5031.

Colgan, P. 2002. Review of J.-P. Hautecoeur (Editor): Ecological Education in Everyday Life ALPHA 2000. Canadian Book Review Annual: 5032.

Colgan, P. 2002. Review of J. I. McKenzie: Environmental Politics in Canada: Managing the Commons in the Twentyfirst Century. Canadian Book Review Annual: 5035.

Colgan, P. 2002. Review of P. Dearden and R. Rollins (Editors): Parks and Protected Areas in Canada: Planning and Management. Canadian Book Review Annual: 5037.

Colgan, P. 2002. Review of M. Howlett (Editor): Canadian Forest Policy. Canadian Book Review Annual: 5041.

Colgan, P. 2002. Review of P. Watson: Seal Wars: Twentyfive Years on the Front Lines with the Harp Seals. Canadian Book Review Annual: 5047.

Colgan, P. 2002. Review of C. L. Evans: The War On Weeds. Canadian Book Review Annual: 5050.

Colgan, P. 2002. Review of D. Forsdyke: The Origin of Species Revisited: A Victorian Who Anticipated Modern Developments in Darwin's Theory. Canadian Book Review Annual: 5058.

Colgan, P. 2003. Review of N. Dakin: Complete Encyclopaedia of the Saltwater Aquarium. Canadian Book Review Annual: 1005.

Colgan, P. 2003. Review of M. Bourrie: Hemp: A Short History of the Most Misunderstood Plant and Its Use. Canadian Book Review Annual: 5004.

Colgan, P. 2003. Review of M. de Villiers and S. Hirtle: Sahara: A Natural History. Canadian Book Review Annual: 5009.

Colgan, P. 2003. Review of M. Harris: Waterfalls of Ontario. Canadian Book Review Annual: 5013.

Colgan, P. 2003. Review of J. A. Burnett: A Passion for Wildlife: The History of the Canadian Wildlife Service. Canadian Book Review Annual: 5030.

Colgan, P. 2003. Review of T. H. Fletcher: From Love Canal to Environmental Justice: The Politics of Hazardous Waste on the Canada-U.S. Border. Canadian Book Review Annual: 5032 .

Colgan, P. 2003. Review of J. G. Nelson et al. (Editors): Protected Areas and Regional Planning Imperative in North America. Canadian Book Review Annual: 5033.

Colgan, P. 2003. Review of Marsha A. Sovada and Ludwig Carbyn: The Swift Fox: Ecology and Conservation of Swift Foxes in a Changing World. Canadian Book Review Annual: 5034.

Colgan, P. 2003. Review of R. Bott, P. Murphy, and R. Udell: Learning from the Forest: A Fifty-year Journey Towards Sustainable Forest Management: 5035.

Colgan, P. 2003. Review of M. de Villiers: Water; The Fate of Our Most Precious Reserve. Canadian Book Review Annual: 5036.

Colgan, P. 2004. Review of H. Lahring: Water and Watershed Plants of the Prairie Provinces. Canadian Book Review Annual: 5006.

Received 17 August 2004

Accepted 6 January 2011 